\title{
Efficient plant regeneration system from seed-derived callus of ravenna grass [Erianthus ravennae (L.) Beauv.]
}

\author{
Kazuki Shimomae ${ }^{1}$, Dong Poh Chin ${ }^{1}$, Raham Sher Khan ${ }^{1,2}$, Masahiro Mii ${ }^{1, *}$ \\ ${ }^{1}$ Graduate School of Horticulture, Chiba University, Matsudo, Chiba 271-8510, Japan; ${ }^{2}$ Department of Biotechnology, \\ Abdul Wali Khan University, Mardan 23200, Pakistan \\ *E-mail: miim@faculty.chiba-u.jp Tel \& Fax: +81-47-308-8852
}

Received May 1, 2013; accepted July 21, 2013 (Edited by M. Otani)

\begin{abstract}
An efficient method of plant regeneration from seed-derived callus was established in ravenna grass [Erianthus ravennae (L.) Beauv.], which is an ornamental tall grass as well as an important biomass crop. For callus induction, mature seeds were cultured on media containing different concentrations of 2,4-dichlorophenoxyacetic acid (2,4-D) (0.5, 1, 2 and $4 \mathrm{mg} \mathrm{l}^{-1}$ ) and 6-benzyladenine (BA) (0, 0.1 and $0.2 \mathrm{mg} \mathrm{l}^{-1}$ ) on callus induction using MS medium (Murashige and Skoog 1962) supplemeted with $1 \mathrm{~g} \mathrm{l}^{-1}$ casamino acids, $30 \mathrm{~g} \mathrm{l}^{-1}$ maltose and $8 \mathrm{~g} \mathrm{l}^{-1}$ agar as a basal medium. The highest callus induction was obtained on medium supplemented with $2 \mathrm{mg} \mathrm{l}^{-1} 2,4-\mathrm{D}$ and $0.2 \mathrm{mg} \mathrm{l}^{-1} \mathrm{BA}$, where $96 \%$ of explants formed callus. During the subculture of the calli on the same medium for 4 months, 3 types of calli showing different growth rate, color and morphology were differentiated. By using these 3 types of calli, effects of different concentrations of BA or 6-furfurylaminopurine (kinetin) $\left(0,0.1,0.5,1,2\right.$ and $\left.4 \mathrm{mg} \mathrm{l}^{-1}\right)$ and naphthaleneacetic acid (NAA) $\left(0,0.25,0.5\right.$ and $\left.1 \mathrm{mg} \mathrm{l}^{-1}\right)$ as plant growth regulators on shoot regeneration were evaluated using MS medium with $1 \mathrm{~g}^{-1}$ casamino acids as a basal medium. The highest frequency of shoot formation was obtained in type A callus, which had white and compact nature, on medium containing $30 \mathrm{~g} \mathrm{l}^{-1}$ sucrose, $1 \mathrm{mg} \mathrm{l}^{-1} \mathrm{BA}$ and $0.1-0.25 \mathrm{mg} \mathrm{l}^{-1} \mathrm{NAA}$, where $89.3 \%$ of the calli formed shoots.
\end{abstract}

Key words: Callus induction, Erianthus ravennae (Ravenna grass), grass, plant regeneration, tissue culture.

Ravenna grass [Erianthus ravennae (L.) Beauv.] is a perennial grass native to South Europe and West Asia. This plant species forms large clumps with stout stems of 3-4 $\mathrm{m}$ high with linear leaves of up to $1.5 \mathrm{~m}$ long and possesses tough root systems. It produces beautiful silky and hairy flower plumes with grayish or purplish color of $30-90 \mathrm{~cm}$ long, which becomes white in autumn. Consequently, it has been used as ornamental plant and for stabilizing soil to prevent erosion worldwide. As the genus Erianthus is a wild relative to Saccharum, important traits such as drought and soil salinity resistances have successfully been transferred from Erianthus to Saccharum by intergeneric hybridization (Aitken et al. 2007; D'Hont et al. 1995). Due to its efficient $\mathrm{C}_{4}$ type photosynthesis, high biomass yield, excellent tolerance against various environmental stresses and low input needs (Hattori et al. 2010; Thetford et al. 2009), Erianthus spp. have a great potential to become an important biomass-energy crop (Deren et al. 1991; Samson et al. 2005). There is an increasing interest in the production of bio-fuels including cellulosic bioethanol from biomass grass species such as $E$. ravennae, which are also helpful to reduce ambient $\mathrm{CO}_{2}$ concentration by neutralizing carbon. However, in perennial biomass grass crops, large number of seeds disperses widely and they may become troublesome weeds and alien plants, which may cause adverse effect on environment (Heady 1956; Henry and Scott 1981). For the breeding of Erianthus spp., therefore, it is expected to incorporate important traits such as increased biomass, resistances to pests, diseases, salts and drought, as well as male sterility into these biomass crops by genetic transformation methods. For a successful transformation, however, an efficient regeneration protocol is a prerequisite (Delbreil et al. 1992; Ishida et al. 1996; Zhao et al. 2000).

In Erianthus, callus induction and plant regeneration of E. elephantinus Hook. F. and E. arundinaceus (Retz.) Jeswiet have been achieved (Jalaja and Sreenivasan 1999; Uwatoko et al. 2011). However, no detailed studies for callus formation and shoot regeneration have been reported for E. ravennae. In the present study, therefore, we report for the first time a highly efficient callus induction and plant regeneration system from seeds of E. ravennae. Our system might be used for efficient propagation of elite clones and to improve various traits in this species by genetic transformation.

Abbreviations: 2,4-D, 2,4-dichlorophenoxyacetic acid; BA, 6-benzyladenine; MS, Murashige and Skoog; HF, hormone-free; NAA, naphthaleneacetic acid; kinetin; 6-furfurylaminopurine.

This article can be found at http://www.jspcmb.jp/

Published online November 14, 2013 


\section{Materials and methods}

\section{Plant material and callus induction}

Mature seeds of Erianthus ravennae (L.) Beauv. purchased from a commercial source (Pase Seeds, New York, USA; Lot number 173042) were used for establishing an efficient plant regeneration system through callus induction. The seeds were surface-sterilized by soaking in $70 \%(\mathrm{v} / \mathrm{v})$ ethanol for $1 \mathrm{~min}$ and then $1 \%(\mathrm{v} / \mathrm{v})$ sodium hypochlorite solution containing a few drops of Tween-20 for $15 \mathrm{~min}$, and rinsed 3 times with sterile water. The seeds were then cultured for callus induction on Murashige and Skoog (MS) basal medium (Murashige and Skoog 1962) supplemented with both 2,4-D (2,4-dichlorophenoxyacetic acid; Wako Pure Chemical Industries, Ltd., Osaka, Japan) at 0.5, 1, 2 and $4 \mathrm{mg} \mathrm{l}^{-1}$ and BA (6-benzyladenine; Wako Pure Chemical Industries, Ltd., Osaka, Japan) at $0,0.1$ and $0.2 \mathrm{mg}^{-1}$. Each medium contained $30 \mathrm{~g} \mathrm{l}^{-1}$ maltose, $1 \mathrm{~g} \mathrm{l}^{-1}$ casamino acids (Casamino Acids DAIGO; Nihon Pharmaceutical Co., Ltd., Tokyo, Japan) and was solidified with $8 \mathrm{~g} \mathrm{l}^{-1}$ agar (Wako Pure Chemical Industries, Ltd., Osaka, Japan). The $\mathrm{pH}$ of all media was adjusted to $5.7 \pm$ 1 and then sterilized by autoclaving at $121^{\circ} \mathrm{C}$ at $1.4 \mathrm{~kg} \mathrm{~cm}^{-2}$ for $15 \mathrm{~min}$. The seeds were inoculated in $90 \times 20 \mathrm{~mm}$ plastic Petri dishes, each containing 9 seeds on $40 \mathrm{ml}$ medium, and incubated at $25 \pm 1^{\circ} \mathrm{C}$ and $55-80 \%$ relative humidity. The data were recorded after 2 weeks of culture and the experiment was repeated 3 times.

\section{Subculture of callus}

Primary calli induced from mature seeds on callus induction media with various concentrations of 2,4-D and BA were subcultured on $0.8 \mathrm{~g} \mathrm{l}^{-1}$ agar-solidified MS basal medium supplemented with $2 \mathrm{mg} \mathrm{l}^{-1} 2$,4-D, $1 \mathrm{~g} \mathrm{l}^{-1}$ casamino acids and $30 \mathrm{~g} \mathrm{l}^{-1}$ maltose. For the subculture, the calli were divided into small pieces (50-100 $\mathrm{mg}$ fresh weight), and transferred onto $90 \times 20 \mathrm{~mm}$ plastic Petri dishes, each containing $40 \mathrm{ml}$ medium, by inoculating ca. 50 callus pieces per plate. They were kept under the same dark conditions and subcultured every 2 weeks for 3-5 months.

Three types of calli obtained during the subculture were characterized by their relative water contents and growth rates. Relative water contents of calli were calculated by the following formula: $(\mathrm{Wf}-\mathrm{Wd}) / \mathrm{Wf} \times 100$, where Wf and Wd denote fresh weight and dry weight of callus, respectively. Dry weight was measured after drying at $65^{\circ} \mathrm{C}$ for 4 days in incubator (Incubator IC-300; AS ONE Corporation, Osaka, Japan). Callus growth rate was calculated by dividing final callus fresh weight by initial weight after each subculture of 14 days.

\section{Shoot regeneration from callus}

Four months after subcultures on the callus maintenance medium, the calli induced on MS medium containing $4 \mathrm{mg} \mathrm{l}^{-1}$ 2,4-D and $0.1 \mathrm{mg} \mathrm{l^{-1 }}$ BA were transferred onto MS basal medium supplemented with combinations of different concentrations $\left(0,0.25,0.5\right.$ and $\left.1 \mathrm{mg}^{-1}\right)$ of NAA (naphthaleneacetic acid; Sigma-Aldrich, St. Louis, MO, USA) and either BA or kinetin (6-furfurylaminopurine; SigmaAldrich, St. Louis, MO, USA) at 0.1, 0.5, 1, 2 and $4 \mathrm{mg} \mathrm{l}^{-1}$. Each medium was supplemented with $30 \mathrm{~g} \mathrm{l}^{-1}$ sucrose, $1 \mathrm{~g} \mathrm{l}^{-1}$ casamino acids and solidified with $3 \mathrm{~g} \mathrm{l}^{-1}$ gellan gum (Gelzan ${ }^{\mathrm{TM}}$ CM; Sigma-Aldrich, St. Louis, MO, USA) in $90 \times 20 \mathrm{~mm}$ plastic Petri dishes, each containing $40 \mathrm{ml}$ of medium. The cultures were incubated in growth room at $25 \pm 1^{\circ} \mathrm{C}$ under light conditions with $16 / 8 \mathrm{~h}$ (light/dark) photoperiod of $30-40 \mu \mathrm{mol}$ $\mathrm{m}^{-2} \cdot \mathrm{s}^{-1}$ with cool white florescent light. The same culture conditions were also used for the subsequent root induction and acclimatization processes.

The data of regenerated shoots were recorded after 5 weeks of culture. Plant regeneration was evaluated as the percentage of the number of callus with shoot formation to total number of callus cultured on regeneration medium.

\section{Rooting from regenerated shoots}

Regenerated shoots were detached from calli and transferred onto half-strength MS basal medium supplemented with $30 \mathrm{~g} \mathrm{l}^{-1}$ sucrose and $3 \mathrm{~g} \mathrm{l}^{-1}$ gellan gum in $90 \times 20 \mathrm{~mm}$ plastic Petri dishes until they produce roots and $2 \mathrm{~cm}$ long leaves. Then the rooted plants were transferred onto the same medium in $25 \times 150 \mathrm{~mm}$ glass test tubes.

\section{Acclimatization and cultivation of regenerated plants}

Well grown $(10-12 \mathrm{~cm})$ and rooted plantlets were removed from culture tubes, washed carefully the roots with sterile water to remove the medium, transplanted to $125 \times 75 \mathrm{~mm}$ glass bottles ( 1 shoot per bottle), each containing sterilized medium consisting of $15 \mathrm{~g}$ vermiculite, $15 \mathrm{~g}$ soil and $30 \mathrm{ml}$ distilled water. After 3 weeks of incubation, bottle caps were removed and the plantlets were kept for 1 week at room temperature for acclimatization and further growth. Then they were transferred into pots containing the same mixture of vermiculite and soil, and kept in the greenhouse for further cultivation.

\section{Data analysis}

The data obtained for the callus induction, relative water content, callus growth rate and shoot regeneration were subjected to the analysis of variance (ANOVA) using the SPSS statistical package. Tukey's HSD test was performed to identify significant differences among the treatments, with significance level of $p<0.05$. The arcsine transformation was performed on all percentage data before statistical analysis.

\section{Results and discussion}

\section{Primary callus induction}

Mature seeds of E. ravennae germinated 4-5 days after sowing on MS medium containing different concentrations of 2,4-D and BA under the dark condition. The percentage of germinated seeds on these media ranged from 79 to $85 \%$ and no clear effect of 2,4-D 


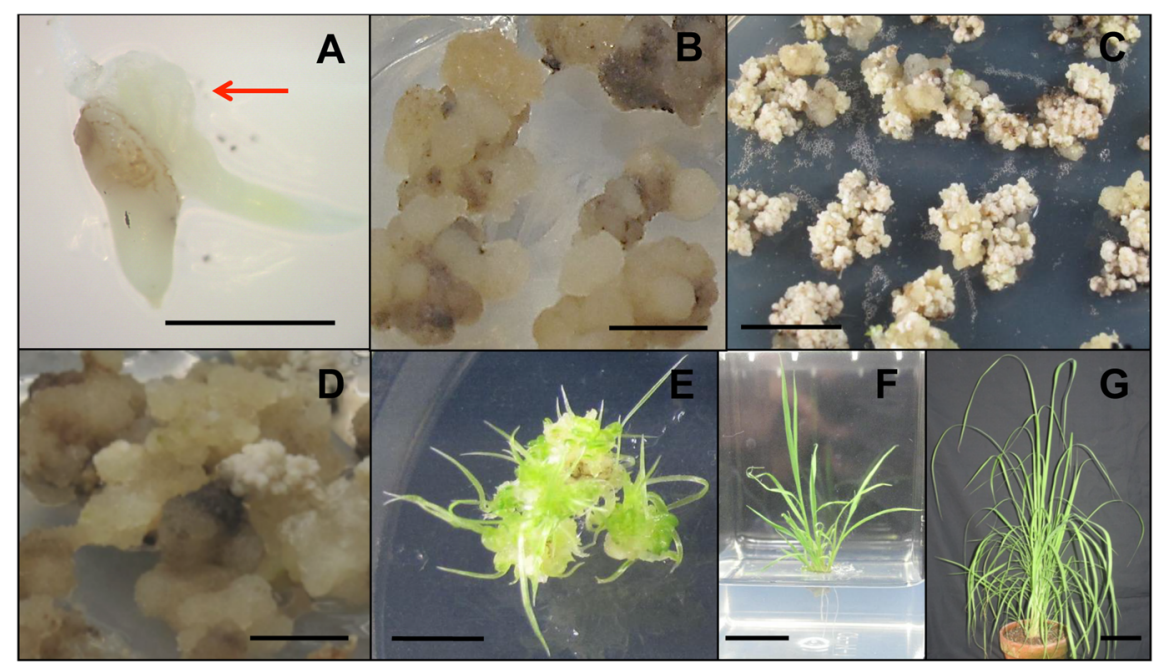

Figure 1. Shoot regeneration from E. ravennae callus. (A) Callus induction from mature seeds of E. ravennae after 10 days of culture on MS medium supplemented with $4 \mathrm{mg} \mathrm{l}^{-1} 2,4-\mathrm{D}$ and $0.1 \mathrm{mg} \mathrm{l}^{-1} \mathrm{BA}$ (bar=1 mm). An arrow indicates the site of initial callus formation. (B) Primary calli from mature seeds after 1 month of culture under dark conditions on MS medium supplemented with $2 \mathrm{mg} \mathrm{l}^{-1} 2,4-\mathrm{D}$ and $0.2 \mathrm{mg} \mathrm{l^{-1 }}$ BA. (C, D) Proliferated calli from each seed after 2 (C) and 3 months (D) of culture under dark conditions on MS medium supplemented with $2 \mathrm{mg}^{-1} 2,4-\mathrm{D}$ and $0.2 \mathrm{mg} 1^{-1} \mathrm{BA}$ (bar $=2 \mathrm{~mm}$ for $\mathrm{c}$ and $5 \mathrm{~mm}$ for $\mathrm{d}$ ). The calli were subcultured every 2 weeks after initiation of culture. (E) Regenerated multi-shoots 2 weeks after transfer the calli onto MS medium supplemented with $1.0 \mathrm{mg} \mathrm{l}^{-1} \mathrm{BA}$ and $0.5 \mathrm{mg} \mathrm{l}^{-1} \mathrm{NAA}$ (bar $=6 \mathrm{~mm}$ ). (F) Rooted plant 2 weeks after transfer the shoot onto hormone-free half-strength MS medium $(\mathrm{bar}=1 \mathrm{~cm})$. (G) A plant with numerous branches established in a pot, 4 months after the transfer of the plantlet shown in to greenhouse conditions ( $\mathrm{bar}=6 \mathrm{~cm}$ ).

Table 1. Effect of various concentrations of 2,4-D and BA on callus induction from mature seeds of Erianthus ravennae (L.) Beauv.

\begin{tabular}{ccc}
\hline $2,4-{\mathrm{D}\left(\mathrm{m} \mathrm{l}^{-1}\right)}$ & ${\mathrm{BA}\left(\mathrm{mg} \mathrm{l}^{-1}\right)}^{\text {Callus induction }^{\mathrm{a}}(\%)}$ \\
\hline 0.5 & 0.0 & $0 \mathrm{c}$ \\
1.0 & 0.0 & $20.6 \mathrm{~b}$ \\
2.0 & 0.0 & $78.6 \mathrm{a}$ \\
2.0 & 0.1 & $89.5 \mathrm{a}$ \\
2.0 & 0.2 & $93.7 \mathrm{a}$ \\
4.0 & 0.0 & $86.2 \mathrm{a}$ \\
4.0 & 0.1 & $95.8 \mathrm{a}$ \\
4.0 & 0.2 & $95.9 \mathrm{a}$ \\
\hline
\end{tabular}

The difference letters indicated a significantly difference at $p<0.05$, as determined by Tukey's HSD test. ${ }^{\text {a }}$ Percentage of callus induction was calculated as (total number of seed with callus formation/total number of germinated seeds) $\times 100$ after 2 weeks of culture.

and $\mathrm{BA}$ on the germination percentage was observed (data not shown). Similar results were obtained in Indian grass (Sorghastrum nutans L.) (Li et al. 2009), in which no clear relationship was observed between germination frequency of mature seeds and the concentrations of plant growth regulators tested.

In many grasses, callus has been induced by single application of auxin or by using a combination of auxin and cytokinin as plant growth regulators in the medium. One of the most commonly used auxins for callus induction of grass species is 2,4-D, which was sometimes used in combination with cytokinins such as BA and kinetin. In sugarcane (Joyce et al. 2010) and centipedegrass (Yuan et al. 2009), callus was efficiently induced on medium supplemented with 2,4-D alone, while 2,4-D together with low level of BA was effective for callus induction in miscanthus (Głowacka et al. 2010), bermudagrass (Chaudhury and Qu 2000) and Kentucky bluegrass (van der Valk et al. 1995). In the present study, mature seeds of $E$. ravennae initiated to produce calli within 10 days of culture in the dark on almost all the culture media expect for 2,4-D free medium (Figure 1A). After 5 weeks of culture, almost $80 \%$ or higher callus induction rates were obtained on medium containing 2-4 $\mathrm{mg} \mathrm{l}^{-1} 2,4-\mathrm{D}$, and co-existence of a low concentration $\left(0.1 \mathrm{mg} \mathrm{l}^{-1}\right)$ of BA slightly increased the percentage at $2 \mathrm{mg} \mathrm{l}^{-1} 2,4-\mathrm{D}$. The highest percentage of callus induction (ca. 96\%) was obtained on medium containing $4 \mathrm{mg} \mathrm{l}^{-1}$ 2,4-D and 0.1-0.2 $\mathrm{mg} \mathrm{l}^{-1} \mathrm{BA}$ (Table 1).

\section{Different type of callus induced during subculture}

It has been reported that repeated subculture of primarily induced callus on the callus induction medium was important for obtaining the callus with shoot regeneration ability (Holme and Petersen 1996; Ntui et al. 2010; Petersen 1997). In zoysia grass, embryogenic callus that had yellow color and compact morphology was obtained after 1 month of subculture (Dhandapani et al. 2008). In the present study, although most of the calli induced from mature seeds had white color and watery nature (Figure 1B), various types of calli (Figure 1C) were formed on the surface of primarily induced watery calli after 2 months of culture. Consequently, 3 type of calli were obtained after 3 months of subcultures under dark conditions on calls maintenance medium containing $2 \mathrm{mg} \mathrm{l}^{-1}$ 2,4-D and $1 \mathrm{gl}^{-1}$ casamino acids (Figure 1D).

The characteristics of the 3 types of calli are as follows: type A with white, compact and easy to convert to primary callus than other types of callus (Figure 2a- 


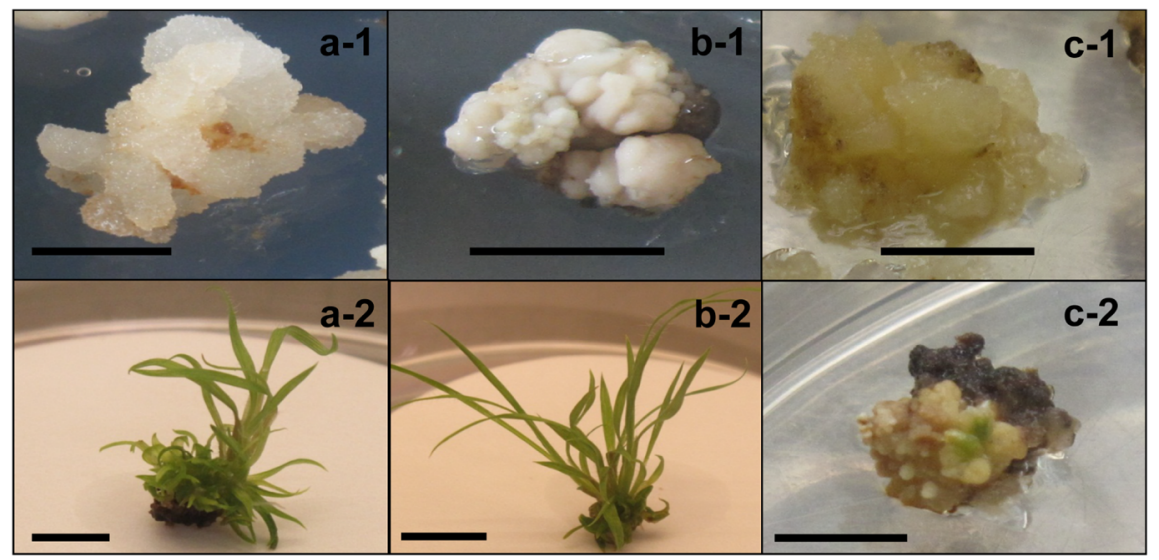

Figure 2. Shoot regeneration of E. ravennae from 3 types of callus (type A, B and C). (1) Three types of calli induced from mature seeds after 3 months of culture under dark conditions on MS medium supplemented with $2 \mathrm{mg} \mathrm{l}^{-1} 2,4-\mathrm{D}$ and $0.1 \mathrm{mg} \mathrm{l^{-1 }}$ BA. (2) Shoot regenerated from 3 types of calli 6 weeks after transfer onto MS medium supplemented with $1 \mathrm{mg} \mathrm{l}^{-1} \mathrm{BA}$ and $0.5 \mathrm{mg} \mathrm{l}^{-1} \mathrm{NAA}$. (a) Type A callus with white color and compact morphology. (b) Type B callus with pure white color and dry and hard morphology. (c) Type C callus with white watery appearance and soft morphology $(\mathrm{bar}=3 \mathrm{~mm})$.

Table 2. Relative water content, callus growth rate and shoot regeneration rate of 3 types of calli of Erianthus ravennae (L.) Beauv.

\begin{tabular}{cccc} 
Callus type $^{\mathrm{a}}$ & $\begin{array}{c}\text { Relative water } \\
\text { content } \\
(\%)^{\mathrm{b}}\end{array}$ & $\begin{array}{c}\text { Shoot } \\
\text { regeneration } \\
(\%)^{\mathrm{c}}\end{array}$ & $\begin{array}{c}\text { Callus growth } \\
\text { rate(fold) }{ }^{\mathrm{d}}\end{array}$ \\
\hline Type A & $89.5 \mathrm{ab}$ & $88.9 \mathrm{a}$ & $2.0 \mathrm{a}$ \\
Type B & $86.1 \mathrm{~b}$ & $51.9 \mathrm{a}$ & $1.5 \mathrm{~b}$ \\
Type C & $93.1 \mathrm{a}$ & $7.4 \mathrm{~b}$ & $1.0 \mathrm{c}$ \\
\hline
\end{tabular}

${ }^{a}$ Characteristics of calli were white and compact (Type A), pure white, dry and hard (Type B), and white or yellow, watery and soft (Type C), respectively. ${ }^{\mathrm{b}}$ Relative water content was calculated as \{(callus fresh weight-callus dry weight)/ callus fresh weight $\} \times 100$. The difference letters indicated a significantly difference at $p<0.05$, as determined by Tukey's HSD test. ${ }^{c}$ The difference letters indicated a significantly difference at $p<0.05$, as determined by Tukey's HSD test. ${ }^{\mathrm{d}}$ Callus growth rate was calculated as (final callus fresh weight/initial callus fresh weight after 2 weeks of culture). Data were expressed as the average of 3 repeated subcultures. The difference letters indicated a significantly difference at $p<0.05$, as determined by Tukey's HSD test.

1); type B with pure white, dry and hard (Figure 2b-1); and type $\mathrm{C}$ with similar nature to primary callus, i.e., white, watery, soft, sticky and slower growth than other types (Figure 2c-1). After one month of culture on maintenance medium, relative water content and growth rates were compared among these 3 types of callus (Table 2 ). As the results, type $C$ callus had higher water content than type A and type B callus, while type A callus showed the highest callus proliferation during the subculture.

\section{Difference in shoot regeneration ability among 3 types of calli}

When these 3 types of calli were transferred onto shoot regeneration medium containing $1 \mathrm{mg} \mathrm{l}^{-1} \mathrm{BA}$, $0.25 \mathrm{mg} \mathrm{l}^{-1} \mathrm{NAA}$ and $1 \mathrm{~g} \mathrm{l}^{-1}$ casamino acids and cultured under light condition, the type A compact callus showed higher shoot regeneration ability (88.9\%) than the type $\mathrm{B}$ and type $\mathrm{C}$ compact calli. In type $\mathrm{A}$ callus, purple and green spots appeared soon after the transfer and the green spots developed into shoot buds after 1 week of culture. They developed into multiple shoots after 3 weeks of culture and attained to be longer than $15 \mathrm{~mm}$ in length after 6 weeks (Figure 2a-2). In type B callus, shoot buds developed into the same size of shoots only after 3 weeks of culture (Figure 2b-2), suggesting its earlier shoot regeneration ability than the type A callus although $82.5 \%$ of type B callus turned brown. In contrast, type $C$ callus rarely regenerated shoots, and $90 \%$ of the calli remained highly moistened and non-compact (Figure 2c-2). According to these results, we selected type A callus for shoot regeneration in the following experiments since it showed high ability for callus proliferation and shoot regeneration.

\section{Effects of cytokinin on shoot regeneration}

Since type A callus showed higher rates of both callus proliferation and shoot regeneration than other two types of callus, it was selected as the material for comparing the effect of two cytokinins, BA and kinetin, in combination with NAA as an auxin, on the shoot regeneration under light condition. Shoot regeneration occurred on all tested media after 2 weeks of culture (Figure 1E) even in the absence of plant growth regulators although the frequency was low (Figures 3 and 4). On medium containing $1 \mathrm{mg} \mathrm{l}^{-1} \mathrm{BA}$ in combination with 0.1 to $0.25 \mathrm{mg} \mathrm{l}^{-1} \mathrm{NAA}$, the shoots were produced at the highest percentage (ca. 90\%) after 5 weeks of culture (Figure 3). In contrast, higher concentration $\left(1 \mathrm{mg} \mathrm{l}^{-1}\right)$ of NAA inhibited shoots regeneration and sometimes induced albino shoots. Higher concentrations of BA (2 and $4 \mathrm{mg} \mathrm{l}^{-1}$ ) inhibited not only shoot regeneration but also callus or shoots growth irrespective of the concentrations of NAA.

Replacement of BA by kinetin gave reduced efficiency of shoot regeneration from callus and slow shoot growth at all the concentrations tested (0.1-4 $\left.\mathrm{mg} \mathrm{l}^{-1}\right)$, and the highest efficiency was ca. 70\%, which was obtained on medium containing $1 \mathrm{mg} \mathrm{l}^{-1}$ kinetin and $0.5 \mathrm{mg} \mathrm{l}^{-1}$ 


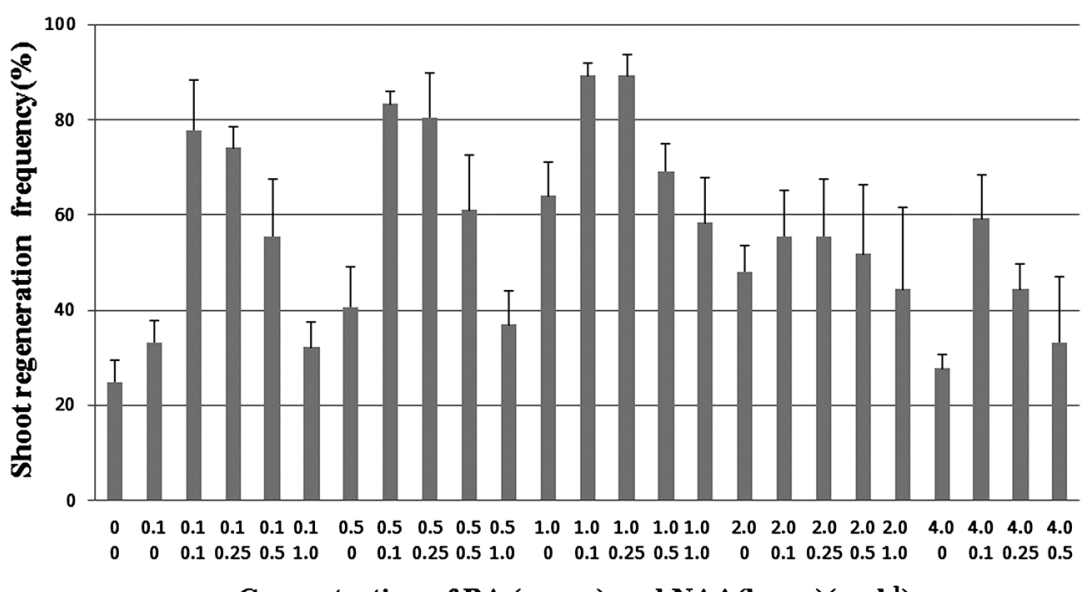

Concentration of BA (upper) and NAA(lower) $\left(\mathrm{mgl}^{-1}\right)$

Figure 3. Effects of BA and NAA on shoot regeneration frequency of E. ravennae callus. The frequency of shoot regeneration was recorded after 5 weeks of culture on shoot regeneration medium containing different concentrations $\left(\mathrm{mg} \mathrm{l}^{-1}\right)$ of BA and NAA. Each value represents a mean \pm S.E. of 3 independent experiments.

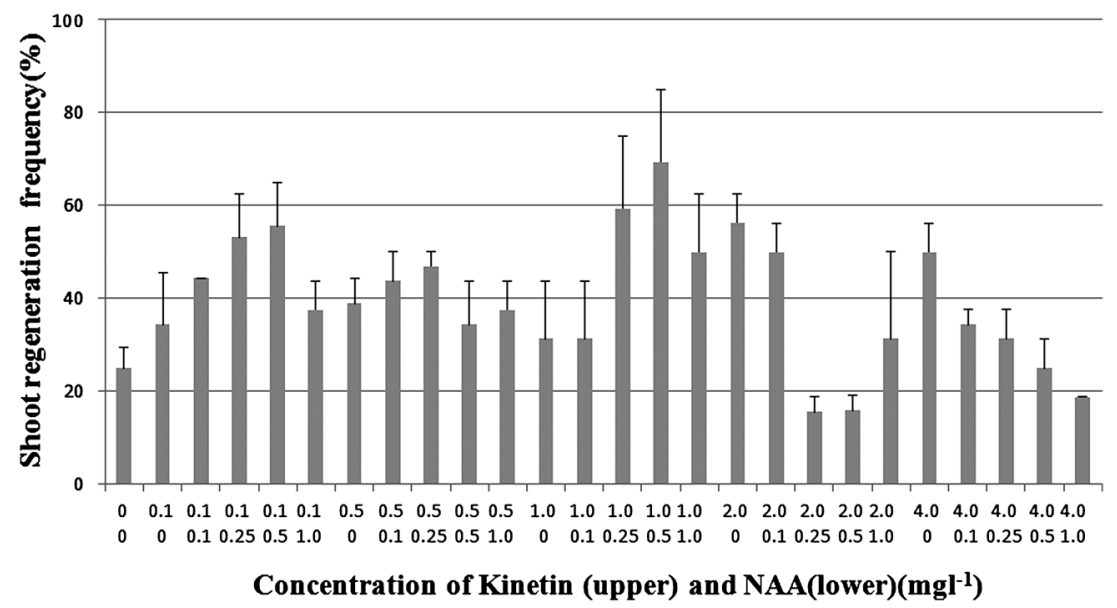

Figure 4. Effects of kinetin and NAA on shoot regeneration frequency of E. ravennae callus. The frequency of shoot regeneration was recorded after 5 weeks of culture on shoot regeneration medium containing different concentrations $\left(\mathrm{mg} \mathrm{l}^{-1}\right)$ of kinetin and NAA. Each value represents a mean \pm S.E. of 3 independent experiments.

NAA (Figure 4). The difference in shoot regeneration rates according to the kind of cytokinin was reported previously in bahiagrass (Grando et al. 2002) and switchgrass (Denchev and Conger 1994, 1995).

\section{Shoot growth and rooting}

The shoots produced in vitro were green and healthylooking but had poorly developed root system. Therefore, shoots were transferred to glass test tubes containing hormone-free half-strength MS medium containing $30 \mathrm{~g} \mathrm{l}^{-1}$ sucrose, solidified with $3 \mathrm{~g} \mathrm{l}^{-1}$ gellan gum, for development of root system (Figure $1 \mathrm{G}$ ). On this medium, rooting rate of shoots one month after the transfer reached $86.5 \%$, though roots developed slowly. These in vitro plants grew slowly at the initial stage but initiated vigorous growth 3 weeks after the transfer. Six weeks after transfer onto the hormone-free half-strength MS medium, plantlets were transplanted to the plastic pots containing a mixture of vermiculite and garden soil and kept in the greenhouse. Four months after the transfer to the greenhouse, all the plants grew normally to $20-30 \mathrm{~cm}$ in height (Figure $1 \mathrm{H}$ ).

In this study, we have successfully established the efficient method of plant regeneration system from seedderived callus of ravenna grass by using MS medium containing 2,4-D and BA. Further studies on genetic transformation of ravenna grass are now in progress by using the plant regeneration system.

\section{References}

Aitken K, Li J, Wang L, Qing C, Fan YH, Jackson P (2007) Characterization of intergeneric hybrids of Erianthus rockii and Saccharum using molecular markers. Genet Resour Crop Evol 54: 1395-1405

Chaudhury A, Qu R (2000) Somatic embryogenesis and plant regeneration of turf-type bermudagrass: Effect of 6-benzyladenine in callus induction medium. Plant Cell Tissue Organ Cult 60: 113-120 
Delbreil B, Guerche P, Jullien M (1993) Agrobacterium-mediated transformation of Asparagus officinalis L. long-term embryogenic callus and regeneration of transgenic plants. Plant Cell Rep 12: 129-132

Denchev PD, Conger BV (1994) Plant regeneration from callus cultures of switchgrass. Crop Sci 34: 1623-1627

Denchev PD, Conger BV (1995) In vitro culture of switchgrass: Influence of 2,4-D and picloram in combination with benzyladenine on callus initiation and regeneration. Plant Cell Tissue Organ Cult 40: 43-48

Deren CW, Snyder GH, Tai PYP, Turick CE, Chynoweth DP (1991) Biomass production and biochemical methane potential of seasonally flooded inter-generic and inter-specific Saccharum hydrids. Bioresour Technol 36: 179-184

Dhandapani M, Hong S, Aswath CR, Kim DH (2008) Regeneration of zoysia grass (Zoysia matrella L. Merr.) cv. Konhee from young inflorescences and stem nodes. In Vitro Cell Dev Biol Plant 44: $8-13$

D’Hont A, Rao PS, Feldmann P, Grivet L, Islam FN, Taylor P, Glasmann JC (1995) Identification and characterisation of sugarcane intergeneric hybrids, Saccharum officinarum $\times$ Erianthus arundinaceus, with molecular markers and DNA in situ hybridisation. Theor Appl Genet 91: 320-326

Głowacka K, Jezowski S, Kaczmarek Z (2010) The effects of genotype, inflorescence developmental stage and induction medium on callus induction and plant regeneration in two Miscanthus species. Plant Cell Tissue Organ Cult 102: 79-86

Grando MF, Franklin CI, Shatters RG Jr (2002) Optimizing embryogenic callus production and plant regeneration from 'Tifton 9' bahiagrass seed explants for genetic manipulation. Plant Cell Tissue Organ Cult 71: 213-222

Hattori T, Shiotsu F, Doi T, Morita S (2010) Suppression of tillering in Erianthus ravennae (L.) Beauv. due to drought stress at establishment. Plant Prod Sci 13: 252-255

Heady HF (1956) Changes in a California annual plant community induced by manipulation of natural mulch. Ecology 37: 798-812

Henry RD, Scott AR (1981) Time of introduction of the alien component of the spontaneous Illinois vascular flora. Am Midl Nat 106: 318-324

Holme IB, Petersen KK (1996) Callus induction and plant regeneration from different explant types of Miscanthus $\times$ ogiformis Honda 'Giganteus'. Plant Cell Tissue Organ Cult 45: $43-52$
Ishida Y, Saito H, Ohta S, Hiei Y, Komari T, Kumashiro T (1996) High efficiency transformation of maize (Zea mays L.) mediated by Agrobacterium tumefaciens. Nat Biotechnol 14: 745-750

Jalaja NC, Sreenivasan TV (1999) In vitro regeneration and cytological studies on somaclones of Erianthus elephantinus Hook. F. Sugar Tech 1: 132-138

Joyce P, Kuwahata M, Turner N, Lakshmanan P (2010) Selection system and co-cultivation medium are important determinants of Agrobacterium-mediated transformation of sugarcane. Plant Cell Rep 29: 173-183

Li Y, Gao J, Fei S (2009) High frequency in vitro embryogenic callus induction and plant regeneration from indiangrass mature caryposis. Sci Hortic (Amsterdam) 119: 306-309

Murashige T, Skoog F (1962) A revised medium for rapid growth and bioassays with tobacco tissue cultures. Physiol Plant 15: 473-497

Ntui VO, Azadi P, Hasthanasombut S, Mii M (2010) Plant regeneration from stem segment-derived frable callus of "Fonio". Hort Sci 125: 494-499

Petersen KK (1997) Callus induction and plant regeneration in Miscanthus $\times$ ogiformis Honda 'Giganteus' as influenced by benzyladenine. Plant Cell Tissue Organ Cult 49: 137-140

Samson R, Mani S, Boddey R, Sokhansanj S, Quesada D, Urquiaga S, Reis V, Lem HC (2005) The potential of $\mathrm{C}_{4}$ perennial grasses for developing a global BIOHEAT Industry. Crit Rev Plant Sci 24: 461-495

Thetford M, Norcini JG, Ballard B, Aldrich JH (2009) Ornamental landscape performance of native and nonnative grasses under low-input conditions. Horttechnology 19: 267-285

Uwatoko N, Tanaka M, Saito A, Gau M (2011) Establishment of plant regeneration system in Erianthus arundinaceus (Retz.) Jeswist, a potential biomass crop. Grassl Sci 57: 231-237

van der Valk P, Ruis F, Tettelaar Schrier AM, van de Velde CM (1995) Optimizing plant regeneration from seed-derived callus cultures of Kentucky bluegrass. The effect of benzyladenine. Plant Cell Tissue Organ Cult 40: 101-103

Yuan X, Wang Z, Liu J, She J (2009) Development of a plant regeneration system from seed-derived calluses of centipedegrass [Eremochloa ophiuroides (Munro.) Hack]. Sci Hortic (Amsterdam) 120: 96-100

Zhao ZY, Cai T, Tagliani L, Miller M, Wang N, Pang H, Rudert M, Schroeder S, Hondred D, Selter J, et al. (2000) Agrobacteriummediated sorghum transformation. Plant Mol Biol 44: 789-798 